\title{
The leaves of Crataeva nurvala Buch-Ham. modulate locomotor and anxiety behaviors possibly through GABAergic system
}

\author{
Md Moniruzzaman ${ }^{1,3^{*}}$ (D) Md Abdul Mannan ${ }^{1}$, Md Farhad Hossen Khan ${ }^{1}$, Ariful Basher Abir ${ }^{1}$ and Mirola Afroze ${ }^{2}$
}

\begin{abstract}
Background: Crataeva nurvala Buch-Hum is an indigenous herb, extensively used in traditional medicines of the South Asian countries to treat inflammation, rheumatic fever, gastric irritation, and constipation. Despite this wide range of uses, very little information is known regarding its effects on the central nervous system (CNS). Therefore, this study evaluated the neuropharmacological properties of methanolic extract of Crataeva nurvala leaves (MECN) using a number of behavioral models in animals. This study also identified potentially active phytochemicals in MECN.

Methods: Following MECN administration (at 50, 100 and $200 \mathrm{mg} / \mathrm{kg}$; b.w.) the animals (male Swiss albino mice) were employed in hole-cross test (HCT), open field test (OFT), and rota-rod test (RRT) to evaluate sedative properties, where anxiolytic activities were investigated using elevated plus maze (EPM), light dark box (LDB), and marble burying test (MBT). The involvement of GABAergic system was evaluated using thiopental sodium (TS)-induced sleeping time determination test. Moreover, colorimetric phytochemical tests as well as GC/MS-MS were also conducted to define the phytochemical constituents of MECN.

Results: MECN possesses sedative properties indicated through the dose-dependent inhibition of locomotor activities of the animals in HCT and OFT and motor coordination in RRT. MECN also exhibited prominent anxiolytic properties through decreased burying behavior in MBT, increased time spent and transitions in open arm of EPM, and increased time spent in light compartment of LDB. In addition, the treatments potentiated TS-mediated hypnosis indicating a possible participation of GABAergic system in the observed sedative and anxiolytic activities. Phytochemical screening of MECN revealed 48 different compounds in it. We reviewed and conceive that the sedative and anxiolytic effects could be due to the presence of neuroactive compounds such as phytol, D-allose, and a-Tocopherol in MECN.
\end{abstract}

Conclusion: The present study showed that MECN possesses sedative and anxiolytic potential which could be beneficial in treatment of anxiety and insomnia associated with different psychological disorders.

Keywords: Capparidaceae, Crataeva nurvala, Sedative, Anxiolytic, Medicinal plant, GC/MS-MS

\section{Background}

Sleep disturbance and anxiety are the very common mental health problems world-wide, which have been regarded as underpinning factors to exacerbate different psychiatric diseases. Now-a-days the treatments for insomnia and anxiety consist of several synthetic and semisynthetic chemical

\footnotetext{
* Correspondence: moniruzzaman.babu@yahoo.com

'Department of Pharmacy, Stamford University Bangladesh, 51 Siddeswari road, Dhaka 1217, Bangladesh

${ }^{3}$ Mater Research Institute - UQ at Translational Research Institute, Faculty of Medicine, The University of Queensland, Brisbane QLD 4102, Australia

Full list of author information is available at the end of the article
}

compounds such as benzodiazepines, barbituric acids, and buspirone. However, these drugs have a number of undesirable side effects including amnesia, muscle relaxation, dependence, and tolerance $[1,2]$. Therefore, searching for novel pharmacotherapy particularly from natural sources for neurological and psychiatric diseases has progressed significantly, owing to their better tolerability and fewer side effects. It is also evident that phytotherapies play a beneficial role for the patients who poorly respond to the conventional therapies $[3,4]$. Therefore, the present study aimed to investigate Crataeva nurvala Buch. -Ham., a well-known

(c) The Author(s). 2018 Open Access This article is distributed under the terms of the Creative Commons Attribution 4.0 International License (http://creativecommons.org/licenses/by/4.0/), which permits unrestricted use, distribution, and reproduction in any medium, provided you give appropriate credit to the original author(s) and the source, provide a link to the Creative Commons license, and indicate if changes were made. The Creative Commons Public Domain Dedication waiver (http://creativecommons.org/publicdomain/zero/1.0/) applies to the data made available in this article, unless otherwise stated. 
member of Capparidaceae family, for its sedative and anxiolytic properties.

C. nurvala is a very common, medium-sized branched deciduous tree found in all over South Asian countries including Bangladesh, where the plant is known as Borun or Bonna [5]. Borun is extensively used in the traditional medicines due to its beneficial properties as memory enhancer, promoter of wound healing [6], laxative, lithotrophic, anti-inflammatory, contraceptive, febrifuge, and tonic. The traditional medicine practitioners also use this plant in treatment of kidney and bladder stone, vomiting, rheumatic fever, and gastric irritation [7]. Due to these diverse pharmacological properties, researchers have tried to validate the scientific basis of use of this plant. Their findings provided scientific evidence regarding the analgesic, antidiarrheal, and antinociceptive properties of the ethanol and methanol extracts of the leaves in mice, respectively [8]. On the other hand, Capparidaceae family particularly the genus Crataeva is almost unknown in their effects on the central nervous system. Crataeva religiosa is the only member reviewed to have stimulatory effects of autonomic nervous system [9]. Previously, we have shown that MECN has the potential to alleviate pain responses through controlling CNS, particularly the opioid system [8]. Therefore, we hypothesized that the chemical constituents of MECN might cross blood brain barrier and have capability to modulate brain functions directly. In 2014, Ali et al. and his colleagues reported the sedative effects of MECN using HCT, OFT, and EPM models with a single high dose $(400 \mathrm{mg} / \mathrm{kg})$ of the extract [10]. In our opinion, research outcomes from a single higher dose and a limited number of experimental models are unable to claim a specific pharmacological property, dose dependency, as well as mechanism of action of an agent. Moreover, the phytochemical constituents of MECN is still unknown.

Therefore, these limited study of the family Capparidaceae especially $C$. nurvala on the central nervous system (CNS) influenced us to design present study to investigate the sedative and anxiolytic properties of the extract using different behavioral models in mice.

\section{Methods}

\section{Plant material and extraction}

The leaves of $C$. nurvala were collected from Comilla, Bangladesh, in October 2012. The samples were then authenticated by Bushra Khan, Principal Scientific Officer of Bangladesh National Herbarium, Dhaka, Bangladesh. A voucher specimen (DACB: 37942) has been deposited in the Herbarium for further reference. $250 \mathrm{~g}$ of shed dried powdered leaves were macerated with $500 \mathrm{ml}$ of methanol with occasional stirring for $72 \mathrm{~h}$ at $25 \pm 2{ }^{\circ} \mathrm{C}$ temperature. The filtrate was then collected and made it dry using rotary evaporator and normal air flow resulting in $10.31 \mathrm{~g}$ extract (Yield 4.12\%). This crude extract was further used for the acute toxicity, sedative, anxiolytic activity studies, and phytochemical analysis.

\section{Reagents}

Diazepam and thiopental sodium were purchased from Square Pharmaceuticals Ltd. (Dhaka, Bangladesh). Methanol and tween 20 were procured from Merck (Darmstadt, Germany).

\section{Animals}

Male Swiss albino mice of $20-25$ g body weight were collected from icddr,b. Animals were housed in a standard environment maintaining $12 \mathrm{~h}$ light/dark cycle $(7.00 \mathrm{am}$ to $7.00 \mathrm{pm}), 25 \pm 2{ }^{\circ} \mathrm{C}$ room temperature, and $55-65 \%$ relative humidity. Flake wood shavings were used as bedding materials and icddr,b formulated standard diet and clean water ad libitum were provided in their regular meal. Prior to the experiments, 14 days of acclimatization period was maintained. All experimental animals were treated following the Health guide for the care and use of Laboratory animals (1978) formulated by the National Institute of Health. All protocols conducted in this study comply with the ARRIVE guidelines and were approved by the Institutional Animal Ethics Committee of Stamford University Bangladesh (SUB/IAEC/14.09). Moreover, pentobarbital was used to euthanize the animals following AVMA guidelines for the Euthanasia of Animals (2013).

\section{Drugs and treatments}

Mice were divided into 5 different groups containing 5 animals in each. In all experiments, diazepam at $1 \mathrm{mg} /$ $\mathrm{kg}$ was used as a reference standard and administered through intraperitoneal (i.p.) route 15 min before the experiments. On the other hand, MECN was dissolved in $0.2 \%$ tween 20 and orally administered to the animals at the doses of 50, 100 and $200 \mathrm{mg} / \mathrm{kg}$ body weight (adjusted volume $0.1 \mathrm{ml} /$ mouse). Animals from the control group only received $0.2 \%$ tween 20 (vehicle; p.o.) $30 \mathrm{~min}$ prior to the experiments. Moreover, thiopental sodium (20 mg/kg; i.p.) in sleeping time measurement test was injected 15 min after MECN or diazepam treatments.

\section{Acute toxicity test}

The animals were divided into five consecutive groups containing five animals in each. Animals were kept in close observation for $72 \mathrm{~h}$ and in a total of seven days following the oral treatments with vehicle or MECN at 500, 1000, 2000, and $3000 \mathrm{mg} / \mathrm{kg}$ doses (adjusted volume $0.1 \mathrm{ml} /$ mouse) to check any allergic reaction, swelling, vomiting, diarrhea, and mortality induced by MECN. In the meantime they were allowed to have access to food and water ad libitum [11]. 


\section{Sedative activity analysis Hole cross test}

The hole cross box is a cage of $(30 \times 20 \times 14) \mathrm{cm}^{3}$ in size with a partition in the middle having a hole of $3 \mathrm{~cm}$ in diameter. Mice were treated with vehicle, MECN or diazepam and placed in one chamber of the cage. Then the total number of passages of a mouse through the hole from one compartment to another was counted for a period of $3 \mathrm{~min}$ before and after 30, 60, 90 and $120 \mathrm{~min}$ of the treatments [12]. The percentage of inhibition was calculated for each time point according to the following formula:

$$
\% \text { Inhibition }=[(\text { Control }- \text { Treatment }) / \text { Control }] \times 100
$$

\section{Open field test}

This test is one of the most frequently used methods to evaluate locomotor activity and emotionality of the rodents. The apparatus is a square box consisting of a $50 \mathrm{~cm}$ high wall and a wooden floor with a series of squares alternatively painted in black and white. Animals were administered with vehicle, MECN, or diazepam and placed in the middle of the open field allowing free exploration. The animals were then scored with the number of squares they visited for $3 \mathrm{~min}$ before and at 30, 60, 90 and $120 \mathrm{~min}$ post treatments [13]. The percentage of inhibition was calculated for each time point as described in hole cross test.

\section{Test for motor co-ordination (Rota-rod test)}

The apparatus consists of a non-slippery plastic rod of $3 \mathrm{~cm}$ in diameter (Ugo Basile, Varese, Italy) which rotates at the speed of $20 \mathrm{rpm}$. The animals which were able to stay in the rotating rod for more than $180 \mathrm{~s}$ were selected for the study. Animals were then treated with vehicle or MECN or diazepam and placed on the rotating rod to register their falling latency from the rod within $180 \mathrm{~s}[14,15]$. The percentage of inhibitions were calculated as described in hole cross test.

\section{Anxiolytic activity analysis Elevated plus-maze test (EPM)}

The plus-maze apparatus is consisting of two open arms $\left(15 \times 5 \mathrm{~cm}^{2}\right)$ and two closed arms $\left(15 \times 5 \times 5 \mathrm{~cm}^{3}\right)$ extending from a central platform $\left(5 \times 5 \mathrm{~cm}^{2}\right)$, and raised $50 \mathrm{~cm}$ above the floor level. Animals were randomly selected for each group and treated with vehicle, MECN, or drug. Then each animal was placed at the center of the plus-maze and allowed them to freely access the maze for $3 \mathrm{~min}$. The number of entries and total time spent in open arms were then recorded within the indicated time [16].

\section{Light-dark box exploration test (LDB)}

The apparatus is an open-topped rectangular box ( $46 \times$ $\left.27 \times 30 \mathrm{~cm}^{3}\right)$, divided into a small $\left(18 \times 27 \mathrm{~cm}^{2}\right)$ and a large $\left(27 \times 27 \mathrm{~cm}^{2}\right)$ compartments with a fixed partition containing a small hole $(3 \mathrm{~cm}$ in diameter) in the middle. The small compartment was closed with a lid, painted black and illuminated with a dim light. On the other hand, the large compartment was painted in white and a $60 \mathrm{~W}$ electric bulb was hanged on at the top (120 cm above) to brightly illuminate it. Mice were treated with vehicle, MECN, or diazepam and placed in the middle of the open compartment. Then the time spent by the animals in open compartment and total number of transitions between the compartments were recorded for $3 \mathrm{~min}[17,18]$.

\section{Marble burying test (MBT)}

A normal glass cage with bedding materials was used in this experiment. Before testing, individual animal was acclimatized in one cage for $30 \mathrm{~min}$. After removal of the animal, 25 glass marbles were uniformly distributed on top of the $4 \mathrm{~cm}$ layer of bedding materials. Following MECN, vehicle, or diazepam treatment, each animal was replaced in the cage for $30 \mathrm{~min}$. The number of buried marbles were then counted as a score of anxiety [19]. The percentage of inhibitions were calculated as described in hole cross test.

Table 1 Effect of MECN on hole cross test

\begin{tabular}{lllllll}
\hline Treatment & Dose $(\mathrm{mg} / \mathrm{kg})$ & \multicolumn{5}{l}{ Number of hole crossed (\% of Inhibition) } \\
\cline { 3 - 7 } & & Pretreatment & $30 \mathrm{~min}$ & $60 \mathrm{~min}$ & $90 \mathrm{~min}$ & $120 \mathrm{~min}$ \\
\hline Control & $0.1 \mathrm{ml} / \mathrm{mouse}$ & $23.40 \pm 1.21$ & $18.60 \pm 1.44$ & $18.20 \pm 1.36$ & $17.00 \pm 1.22$ & $15.60 \pm 1.08$ \\
Diazepam & 1 & $21.40 \pm 2.32$ & $6.20 \pm 1.07^{* * *}(66.67)$ & $3.80 \pm 0.58^{* * *}(79.12)$ & $2.60 \pm 0.51^{* * *}(84.71)$ & $1.40 \pm 0.24^{* * *}(91.03)$ \\
MECN & 50 & $22.80 \pm 1.28$ & $15.40 \pm 0.93(17.20)$ & $11.80 \pm 0.73^{* * *}(35.16)$ & $7.80 \pm 0.86^{* * *}(54.12)$ & $6.00 \pm 0.71^{* * *}(61.54)$ \\
MECN & 100 & $20.60 \pm 1.86$ & $10.60 \pm 0.75^{* * *}(43.01)$ & $9.00 \pm 0.71^{* * *}(50.55)$ & $4.60 \pm 0.93^{* * *}(72.94)$ & $3.80 \pm 0.86^{* * *}(75.64)$ \\
MECN & 200 & $21.20 \pm 1.85$ & $8.00 \pm 0.71^{* * *}(56.99)$ & $5.20 \pm 0.73^{* * *}(71.43)$ & $2.40 \pm 0.51^{* * *}(85.88)$ & $1.60 \pm 0.24^{* * *}(89.74)$ \\
\hline
\end{tabular}

Effect of MECN on hole cross test. Values are presented as the Mean \pm SEM $(n=5)$. MECN = Methanolic extract of Crataeva nurvala; ${ }^{* * *} p<0.001$ compared with the control group (two-way ANOVA followed by Bonferroni's test) 
Table 2 Effect of MECN on open field test

\begin{tabular}{lllllll}
\hline Treatment & Dose $(\mathrm{mg} / \mathrm{kg})$ & \multicolumn{5}{l}{ Number of square crossed (\% of Inhibition) } \\
\cline { 3 - 7 } & & Pretreatment & $30 \mathrm{~min}$ & $60 \mathrm{~min}$ & $90 \mathrm{~min}$ & $120 \mathrm{~min}$ \\
\hline Control & $0.1 \mathrm{ml} / \mathrm{mouse}$ & $103.80 \pm 3.51$ & $94.40 \pm 4.31$ & $83.20 \pm 3.09$ & $74.60 \pm 3.20$ & $66.80 \pm 2.58$ \\
Diazepam & 1 & $101.60 \pm 3.89$ & $49.20 \pm 2.13^{* * *}(47.88)$ & $33.20 \pm 1.88^{* * *}(60.10)$ & $14.80 \pm 1.28^{* * *}(80.16)$ & $5.40 \pm 1.12^{* * *}(91.92)$ \\
MECN & 50 & $98.00 \pm 2.83$ & $67.40 \pm 3.79^{* * *}(28.60)$ & $42.00 \pm 2.49^{* * *}(49.52)$ & $31.60 \pm 2.87^{* * *}(57.64)$ & $16.20 \pm 2.40^{* * *}(75.75)$ \\
MECN & 100 & $100.80 \pm 2.62$ & $46.40 \pm 2.75^{* * *}(50.85)$ & $35.80 \pm 2.48^{* * *}(56.97)$ & $16.20 \pm 4.53^{* * *}(78.28)$ & $5.60 \pm 0.75^{* * *}(91.62)$ \\
MECN & 200 & $102.20 \pm 3.44$ & $34.40 \pm 3.23^{* * *}(63.56)$ & $22.20 \pm 3.88^{* * *}(73.32)$ & $10.80 \pm 2.89^{* * *}(85.52)$ & $4.20 \pm 0.58^{* * *}(93.71)$ \\
\hline
\end{tabular}

Effect of MECN on open field test. Values are presented as the Mean \pm SEM $(n=5)$. MECN $=$ Methanolic extract of Crataeva nurvala; ${ }^{* * *} p<0.001$ compared with the control group (two-way ANOVA followed by Bonferroni's test)

\section{Thiopental sodium-induced sleeping time test}

The animals were randomly divided into desired groups and administered with vehicle, MECN, or diazepam. Thirty min after vehicle or MECN and $15 \mathrm{~min}$ after standard drug, thiopental sodium (TS) was administered to each animal i.p. at a dose of $20 \mathrm{mg} / \mathrm{kg}$. Then animals were observed for the latent period (time between TS administration and loss of their righting reflex) and the duration of sleep (time between the loss and recovery of righting reflex)-induced by TS [14].

\section{Phytochemical analysis}

MECN was qualitatively evaluated to detect the presence of alkaloids, carbohydrates, glycosides, flavonoids, tannins, and reducing sugars according to the protocols described by Ghani et al. [20].

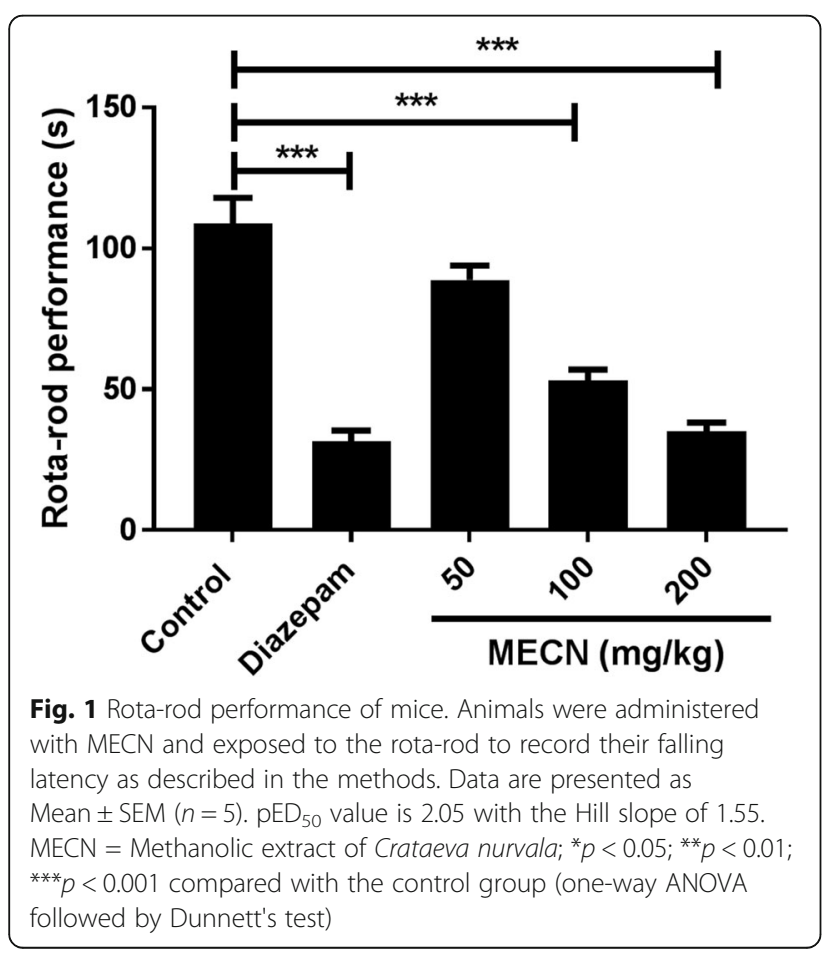

\section{GC/MS-MS analysis}

GC/MS-MS analysis of the methanolic extract of the leaves of $C$. nurvala was carried out using GCMS-TQ8040 gas chromatograph mass spectrometer (Shimadzu Corp., Kyoto, Kyoto Prefecture, Japan) with a Rxi-5 ms fused silica capillary column $(30 \mathrm{~m} \times 0.25 \mathrm{~mm} \times$ $0.25 \mu \mathrm{m}$ film thickness). For GC, the injection temperature was set at $250{ }^{\circ} \mathrm{C}$. The oven temperature was programmed at $50{ }^{\circ} \mathrm{C}$ for $1 \mathrm{~min}, 25^{\circ} \mathrm{C} / \mathrm{min}$ to $125^{\circ}$ $\mathrm{C}$ for $0 \mathrm{~min}$, and $10{ }^{\circ} \mathrm{C} / \mathrm{min}$ to $300{ }^{\circ} \mathrm{C}$ for $10 \mathrm{~min}$. Total analysis time was $31.50 \mathrm{~min}$ where the column flow rate was $1.69 \mathrm{ml} / \mathrm{min}$ Helium gas. The MS was electron ionization (EI) type and set in Q3 scan mode. The ion source temperature was maintained at $200{ }^{\circ} \mathrm{C}$ and the interface at $250{ }^{\circ} \mathrm{C}$. The detector voltage was set at $0.2 \mathrm{kV}$ and the mass range was $50-1000 \mathrm{~m} / \mathrm{z}$. The individual compound was searched and identified using "NIST-MS Library 2009". Total Ionic Chromatogram (TIC) was used to determine the peak area as well as the percentage amounts of each compound.

\section{Statistical analyses}

The results are presented as Mean \pm SEM. The statistical analysis was performed using one-way analysis of variance (ANOVA) followed by Dunnett's post hoc test, except for the HCT and OFT. For these tests, two-way ANOVA followed by Bonferroni's post hoc tests was adopted. In all the cases $P<0.05$ was considered as significant. All statistical analysis was performed using SPSS software. Moreover, the $\mathrm{pED}_{50}$ and Hill Slope values were calculated using Graphpad Prism software.

\section{Results}

Hole cross and open field tests

Our results demonstrated that MECN significantly decreased the spontaneous locomotor activity in mice which is evident in both HCT $\left(F_{4,100}=90.67, p<0.001\right)$ and OFT $\left(F_{4,100}=232.9, p<0.001\right)$ models. The suppressive effect was observed at $30 \mathrm{~min}$ after oral administration with all MECN doses (50, 100 and $200 \mathrm{mg} / \mathrm{kg}$ ) and continued up to $120 \mathrm{~min}$ of the observation period. However, the major drawbacks of these models are the 

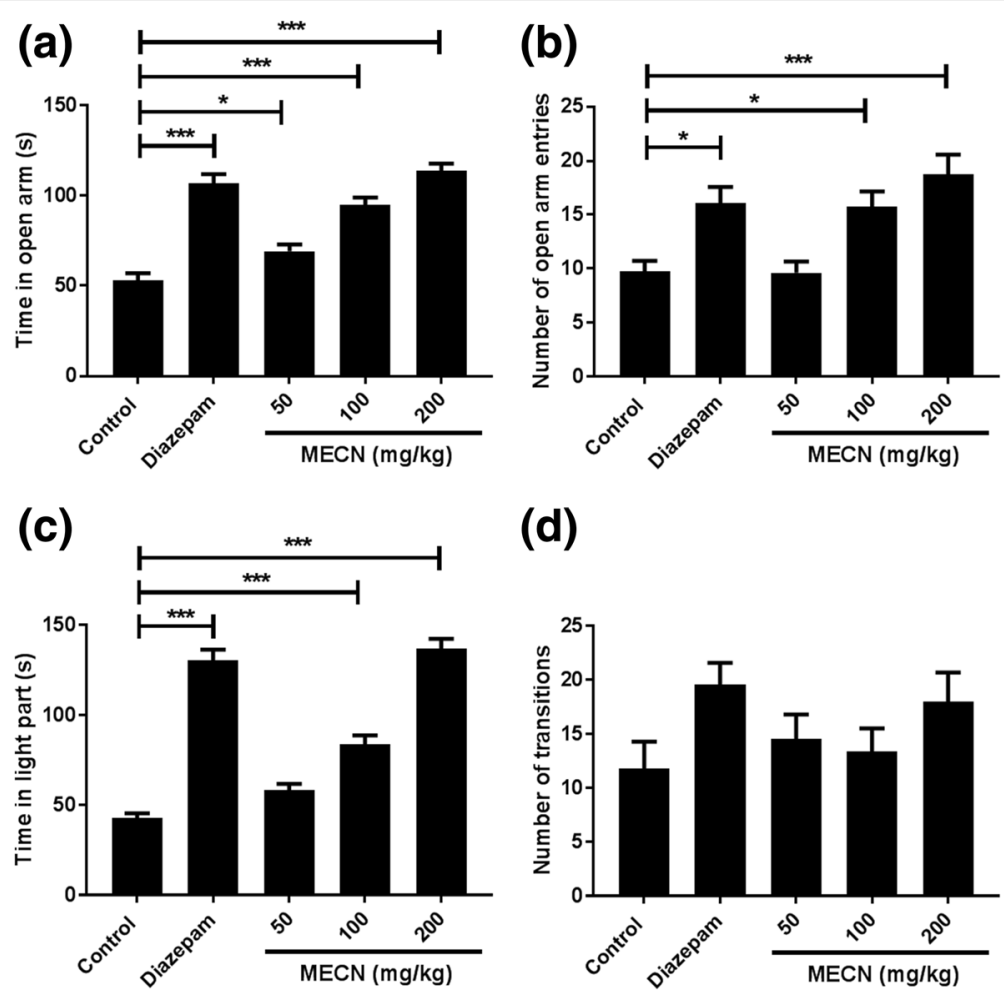

(d)

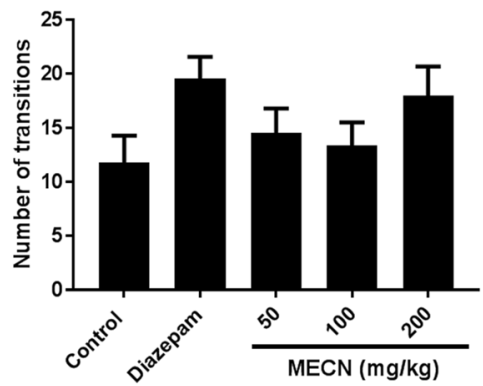

Fig. 2 Effects of MECN on elevated plus maze (EPM) and light-dark box (LDB) tests. Following 30 min of drugs administration, animals were

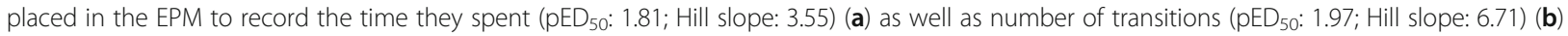
in the open arm. In LDB, mice were observed for the time spent ( $p E D_{50}$ : 1.74; Hill slope: 6.65) (c) and total number of transitions ( $p E D_{50}$ : 2.33; Hill slope: 1.35) (d) in the open lighted compartment. Data are presented as Mean \pm SEM $(n=5)$. MECN = Methanolic extract of Crataeva nurvala; ${ }^{*} p<0.05 ;{ }^{* *} p<0.01 ;{ }^{* *} p<0.001$ compared with the control group (one-way ANOVA followed by Dunnett's test)

animals get habituated and lost their curiosity due to repeated exposure in the same environment, which result in a decrease in their ambulatory activities. As expected, we observed the same results with animals from the control group. However, the decrements with MECN doses are higher and dose-dependent. As the locomotor activity of the animals has been decreased with time and doses, we performed two-way ANOVA analysis followed by Bonferroni's post hoc test and found the effects of MECN are significantly $(P<0.05)$ different from the control group (Tables 1 and 2).

Table 3 Effect of MECN on marble burying test

\begin{tabular}{llll}
\hline Treatment & Dose $(\mathrm{mg} / \mathrm{kg})$ & Responses \\
\cline { 3 - 4 } & & Numbers of marbles buried & $\%$ Inhibition \\
\hline Control & $0.1 \mathrm{ml} / \mathrm{mouse}$ & $11.80 \pm 2.52$ & 0 \\
Diazepam & 1 & $1.20 \pm 0.20^{* *}$ & 89.83 \\
MECN & 50 & $9.40 \pm 2.23$ & 20.34 \\
MECN & 100 & $5.00 \pm 2.10^{*}$ & 57.63 \\
MECN & 200 & $2.20 \pm 0.58^{* *}$ & 81.36
\end{tabular}

Effect of MECN on marble burying test. Values are presented as the Mean \pm SEM $(n=5)$. MECN = Methanolic extract of Crataeva nurvala; ${ }^{*} p<0.05 ;{ }^{* *} p<$ 0.01; compared with the control group (one-way ANOVA followed by Dunnett's test)

\section{Test for motor co-ordination}

As depicted in Fig. 1, the results showed that acute oral administration with MECN (50, 100 and $200 \mathrm{mg} / \mathrm{kg}$ doses) decreased the time that the mice were able to stay on the rota-rod. The highest performance inhibitions were observed with diazepam (71.01\%) and MECN at $200 \mathrm{mg} / \mathrm{kg}$ (67.76\%). Although, MECN dose-dependently suppressed motor co-ordination of the animals, the significant $\left(F_{4,20}=39.13, p<0.001\right)$ inhibition was found with only higher doses of the extract (100 and $200 \mathrm{mg} / \mathrm{kg}$ ). The estimated $\mathrm{pED}_{50}$ value is 2.05 with the Hill slope of 1.55 .

Table 4 Effect of MECN on thiopental sodium induced hypnosis

\begin{tabular}{llll}
\hline Treatment & Dose $(\mathrm{mg} / \mathrm{kg})$ & Responses \\
\cline { 3 - 4 } & & Onset of sleeping & Sleeping duration \\
\hline Control & $0.1 \mathrm{ml} /$ mouse & $9.24 \pm 0.25$ & $50.20 \pm 1.86$ \\
Diazepam & 1 & $6.97 \pm 0.19^{* * *}$ & $98.40 \pm 3.83^{* * *}$ \\
MECN & 50 & $8.87 \pm 0.60$ & $49.00 \pm 4.85$ \\
MECN & 100 & $7.92 \pm 0.27^{*}$ & $69.60 \pm 3.12^{*}$ \\
MECN & 200 & $7.18 \pm 0.28^{* *}$ & $92.20 \pm 2.44^{* * *}$
\end{tabular}

Effect of MECN on thiopental sodium induced hypnosis. Values are presented as the Mean $\pm \operatorname{SEM}(n=5)$. MECN = Methanolic extract of Crataeva nurvala; ${ }^{*} p$ $<0.05$; ${ }^{* *} p<0.01 ; * * * p<0.001$ compared with the control group (one-way ANOVA followed by Dunnett's test) 
Table 5 Groups of phytochemicals identified in MECN

\begin{tabular}{|c|c|c|c|}
\hline Phytochemicals & Names of the tests & Expected changes & Results \\
\hline \multirow[t]{5}{*}{ Alkaloids } & Mayer's test & Yellowish buff color precipitate & + \\
\hline & Hager's test & Yellow crystalline precipitate & - \\
\hline & Wagner's test & Brown or deep brown precipitate & + \\
\hline & Dragendorff's test & Orange or orange-brown precipitate & + \\
\hline & Tannic acid test & Buff color precipitate & + \\
\hline \multirow[t]{2}{*}{ Tannins } & Ferric chloride test & Blue green color & + \\
\hline & Alkaline reagent test & Yellow to red precipitate & + \\
\hline \multirow[t]{2}{*}{ Glycosides } & General test & Yellow color & + \\
\hline & Test for glucoside & Production of brick-red precipitation & + \\
\hline \multirow[t]{4}{*}{ Carbohydrates } & Molisch's test & $\begin{array}{l}\text { A red or reddish violet ring is formed } \\
\text { at the junction of two layers, and on } \\
\text { shaking a dark purple solution is formed }\end{array}$ & + \\
\hline & Barfoed's test (general test for monosaccharides) & Red precipitate & + \\
\hline & Fehling's test & A red or brick-red precipitate & + \\
\hline & Test for reducing sugar & A brick-red precipitate & + \\
\hline Flavonoids & Hydrochloric acid reduction test & Red color & + \\
\hline
\end{tabular}

\section{Elevated plus-maze test}

In EPM test, as expected for a positive control, diazepam at $1 \mathrm{mg} / \mathrm{kg}$ produced a selective anxiolytic effect in mice characterized by a significant $\left(F_{4,20}=36.28, p<0.001\right)$ increase in the time spent as well as the number of entries in the open arm of EPM. Besides, treatments with the methanolic extract of C. nurvala at 100 and $200 \mathrm{mg} / \mathrm{kg}$ doses significantly $\left(F_{4,20}=36.28, p<0.001\right)$ increased the spending time $\left(\mathrm{pED}_{50}: 1.81\right.$; Hill slope: 3.55$)$ and total number of entries $\left(F_{4,20}=8.50, p<0.001 ; \mathrm{pED}_{50}: 1.97\right.$; Hill slope: 6.71) in the open arm (Fig. 2a, b).

\section{Light-dark box exploration test}

The results obtained in this test demonstrated a significant $\left(F_{4,20}=78.56, p<0.001\right)$ increase in time spent in LDB light chamber by $\mathrm{MECN}$ ( $\mathrm{pED}_{50}$ : 1.74; Hill slope: 6.65 ). It also increased the number of transitions between compartments in a dose-dependent manner $\left(\mathrm{pED}_{50}: 2.33\right.$; Hill slope: 1.35) (Fig. 2c, d).

\section{Marble burying test}

In this study, the oral administration of MECN at 50, 100 and $200 \mathrm{mg} / \mathrm{kg}$ doses showed dose-dependent and

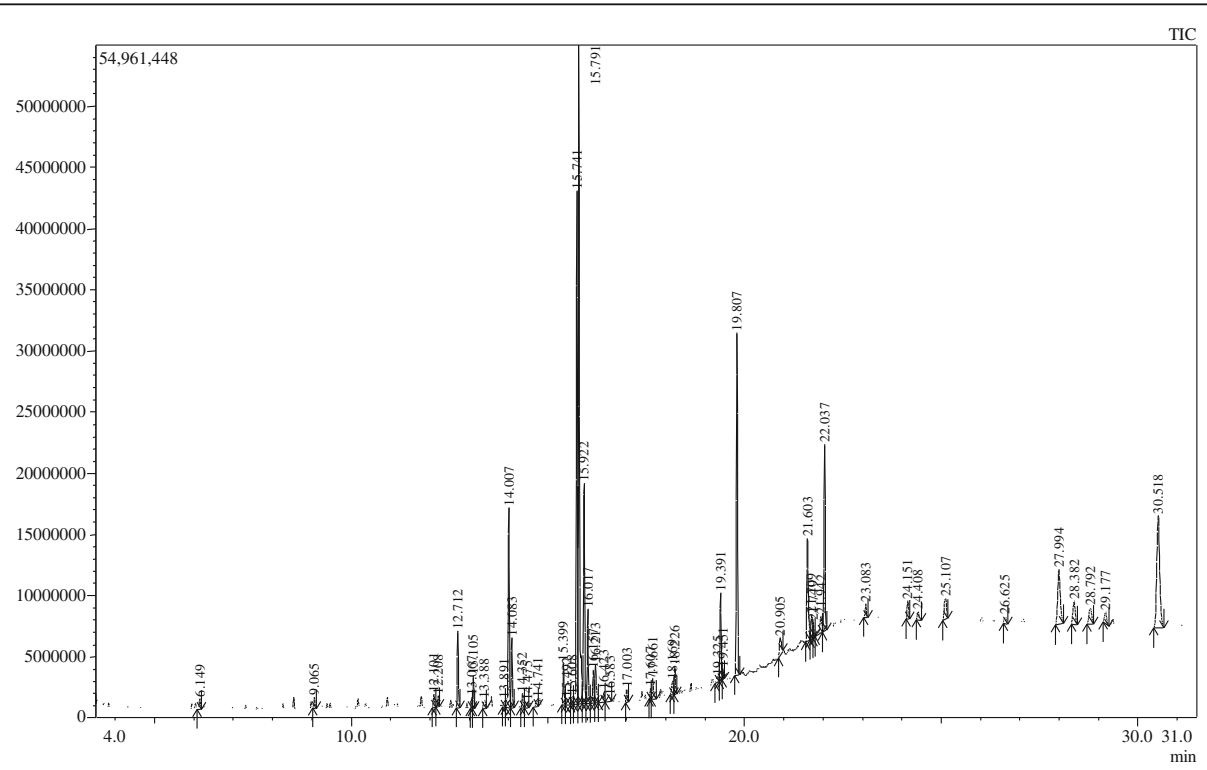

Fig. 3 Total ionic chromatogram of MECN from GC/MS-MS 
Table 6 Phytochemicals detected in MECN using GC/MS-MS

\begin{tabular}{|c|c|c|c|c|c|}
\hline SN & RT (min) & $\%$ PA & Compound name & Biological activity & References \\
\hline 1 & 6.04 & 0.55 & Catechol & Antioxidant & [39] \\
\hline 2 & 6.15 & 0.64 & Butanenitrile, 3-chloro-3-methyl- & Not found & - \\
\hline 3 & 8.98 & 0.44 & n-Tridecan-1-ol & Anti-alcoholic & {$[40]$} \\
\hline 4 & 9.07 & 0.84 & D-Allose & $\begin{array}{l}\text { Hepatoprotective, } \\
\text { immunosuppressant, } \\
\text { antioxidant, and } \\
\text { anticancer. }\end{array}$ & {$[41-44]$} \\
\hline 5 & 10.92 & 0.96 & Megastigmatrienone & Not found & - \\
\hline 6 & 11.1 & 0.70 & 2-Cyclohexen-1-one, 4-(3-hydroxy-1-butenyl)-3,5,5-trimethyl- & Not found & - \\
\hline 7 & 11.78 & 0.90 & Ethanol, 2-(dodecyloxy)- & $\begin{array}{l}\text { Antithyroid, } \\
\text { supress varicose } \\
\text { veins formation. }\end{array}$ & {$[45,46]$} \\
\hline 8 & 11.96 & 0.44 & Cedrol & $\begin{array}{l}\text { Prevent } \\
\text { chemotherapy-induced } \\
\text { alopecia, promote hair } \\
\text { growth, anticancer. }\end{array}$ & {$[47-49]$} \\
\hline 9 & 12.1 & 1.28 & (E)-4-(3-Hydroxyprop-1-en-1-yl)-2-methoxyphenol & Not found & - \\
\hline 10 & 12.21 & 1.05 & 6-Hydroxy-4,4,7a-trimethyl-5,6,7,7a-tetrahydrobenzofuran-2(4H)-one & Not found & - \\
\hline 11 & 12.4 & 0.35 & 5,5,8a-Trimethyl-3,5,6,7,8,8a-hexahydro-2H-chromene & Not found & - \\
\hline 12 & 12.71 & 5.24 & (S,E)-4-Hydroxy-3,5,5-trimethyl-4-(3-oxobut-1-en-1-yl)cyclohex-2-enone & $\begin{array}{l}\text { Anticholinesterase } \\
\text { and antioxidant }\end{array}$ & [50] \\
\hline 13 & 12.94 & 0.44 & 1(2H)-Naphthalenone, 3,4,5,6,7,8-hexahydro- & Not found & - \\
\hline 14 & 13.07 & 0.93 & N,N-Diethylhexylamine & Not found & - \\
\hline 15 & 13.11 & 1.98 & Neophytadiene & Not found & - \\
\hline 16 & 13.18 & 0.58 & Z-28-Heptatriaconten-2-one & Not found & - \\
\hline 17 & 13.39 & 1.02 & Bicyclo[4.1.0]heptan-3-one, 4,7,7-trimethyl-, [1 R-(1.alpha.,4.beta.,6.alpha.)]- & Not found & - \\
\hline 18 & 13.392 & 1.02 & 2,3a-Dimethylhexahydrobenzofuran-7a-ol & Not found & - \\
\hline 19 & 13.89 & 0.73 & 1-(3-Hydroxymethyl-phenyl)-heptan-1-ol & Not found & - \\
\hline 20 & 14.09 & 4.36 & 7,9-Di-tert-butyl-1-oxaspiro(4,5)deca-6,9-diene-2,8-dione & Not found & - \\
\hline 21 & 14.47 & 0.81 & 9-(3,3-Dimethyloxiran-2-yl)-2,7-dimethylnona-2,6-dien-1-ol & Not found & - \\
\hline 22 & 14.48 & 0.84 & 1,4-Dimethyladamantane & Not found & - \\
\hline 23 & 14.74 & 0.49 & Diethylene glycol monododecyl ether & Not found & - \\
\hline 24 & 14.79 & 0.61 & trans-Sinapyl alcohol & Not found & - \\
\hline 25 & 15.92 & 14.84 & Phytol & $\begin{array}{l}\text { Anxiolytic, antitubercular } \\
\text { and anticancer }\end{array}$ & {$[36,51,52]$} \\
\hline 26 & 16.21 & 4.07 & Ethanol, 2,2'-(dodecylimino)bis- & Not found & - \\
\hline 27 & 16.69 & 0.52 & Hexadecane & Not found & - \\
\hline 28 & 18.37 & 0.55 & (2,2,6-Trimethyl-bicyclo[4.1.0]hept-1-yl)-methanol & Not found & - \\
\hline 29 & 18.79 & 0.61 & 7-Hexadecenal, (Z)- & Pheromone & [53] \\
\hline 30 & 19.32 & 1.02 & 2-Methylhexacosane & Not found & - \\
\hline 31 & 19.92 & 0.73 & Ethyl 13-docosenoate(ethyl erucate) & Not found & - \\
\hline 32 & 20.13 & 0.58 & Hexacontane & Not found & - \\
\hline 33 & 20.39 & 0.47 & 7-Methyl-6-oxo-1,2,3,4-tetrahydro-6H-pyrimido[1,2-a]pyrimidine & Not found & - \\
\hline 34 & 21.43 & 1.16 & Cyclopentane, (4-octyldodecyl)- & Not found & - \\
\hline 35 & 21.6 & 8.73 & 13-Docosenamide, (Z)- & Not found & - \\
\hline 36 & 22.29 & 0.52 & a-Tocospiro A & Not found & - \\
\hline 37 & 22.49 & 1.28 & a-Tocospiro B & Not found & - \\
\hline 38 & 24.15 & 1.86 & gamma.-Tocopherol & Anti-inflammatory & {$[54,55]$} \\
\hline
\end{tabular}


Table 6 Phytochemicals detected in MECN using GC/MS-MS (Continued)

\begin{tabular}{|c|c|c|c|c|c|}
\hline SN & $\mathrm{RT}$ (min) & $\%$ PA & Compound name & Biological activity & References \\
\hline 39 & 25.11 & 3.23 & Vitamin E & Antioxidant & [56] \\
\hline 40 & 26.63 & 0.93 & Ergost-5-en-3-ol, (3.beta.)- & Not found & - \\
\hline 41 & 27.08 & 0.49 & Stigmasterol & $\begin{array}{l}\text { Anti-asthmatic, } \\
\text { anti-inflammatory, } \\
\text { anti-proliferative, } \\
\text { anti-bacterial, } \\
\text { acetylcholinesterase } \\
\text { inhibitor }\end{array}$ & {$[57-60]$} \\
\hline 42 & 28.38 & 3.40 & $\beta$-Amyrone & Not found & - \\
\hline 43 & 28.79 & 3.49 & 4-Campestene-3-one & Not found & - \\
\hline 44 & 28.96 & 0.55 & Cholestan-3-one, (5.alpha.)- & Not found & - \\
\hline 45 & 29.18 & 2.30 & Lup-20(29)-en-3-one & $\begin{array}{l}\text { Melanogenesis, } \\
\text { hypolipidemic, } \\
\text { anti-inflammatory, } \\
\text { antidiabetic }\end{array}$ & {$[61-64]$} \\
\hline 46 & 29.35 & 1.08 & 4,22-Cholestadien-3-one & Not found & - \\
\hline 47 & 30.52 & 19.44 & $\gamma$-Sitostenone & Not found & - \\
\hline 48 & 31.14 & 0.93 & Cholesta-4,6-dien-3-one & Not found & - \\
\hline
\end{tabular}

$S N$ serial number, $R T$ retention time, $P A$ peak area

significant $\left(F_{4,20}=6.60, p<0.01\right)$ inhibition of burying behavior of the animals (Table 3 ). The calculated $\mathrm{pED}_{50}$ value for MBT is 1.96 with the Hill slope of 2.09. Therefore, keeping with the results obtained in EPM and LDB tests, these findings support the anxiolytic potential of MECN.

\section{Thiopental sodium-induced sleeping time test}

Our results demonstrated that the acute oral administration of MECN at 50, 100 and $200 \mathrm{mg} / \mathrm{kg}$ reduced the TS-mediated induction of sleep in the animals. However, the significant $\left(F_{4,20}=8.31, p<0.01\right)$ effects were observed with the higher doses of MECN (100 and $200 \mathrm{mg} / \mathrm{kg}$ ) for sleeping onset. These result in prolonged duration of sleep $\left(F_{4,20}=46.14, p<0.001 ; \mathrm{pED}_{50}: 2.07\right.$; Hill slope: 3.50 ) as summarized in Table 4.

\section{Acute toxicity test}

The acute toxicity test revealed that the oral administration of MECN at the doses of 500, 1000 2000, and $3000 \mathrm{mg} / \mathrm{kg}$ did not show any mortality or allergic manifestations during 7 days of the observation period. Therefore, it can be assumed that MECN possesses low toxicity profile and safe within our experimental doses up to the $3000 \mathrm{mg} / \mathrm{kg}$.

\section{Phytochemical analysis}

The preliminary phytochemical analysis revealed the presence of alkaloids, glycosides, carbohydrates, flavonoids, and tannins in MECN (Table 5).

\section{GC/MS-MS analysis}

The GC/MS-MS analysis of MECN confirmed the presence of 48 different compounds (Fig. 3, Table 6). The major 25 compounds identified with \% peak area are $\gamma$-Sitostenone (19.44\%), Phytol (14.84\%), 13-Docosenamide, (Z)- (8.73\%), (S,E)-4-Hydroxy-3,5,5-trimethyl-4-(3-oxobut1-en-1-yl)cyclohex-2-enone (5.24\%), 7,9-Di-tert-butyl-1oxaspiro(4,5)deca-6,9-diene-2,8-dione (4.36\%), Ethanol, 2,2' (dodecylimino)bis- (4.07\%), 4-Campestene-3-one (3.49\%), B-Amyrone (3.40\%) Vitamin E (3.23\%), Lup-20(29)-en-3-one (2.30\%), Neophytadiene (1.98\%), $\gamma$-Tocopherol (1.86\%), (E)-4-(3-Hydroxyprop-1-en-1-yl)-2-methoxyphenol (1.28\%), $\alpha$-Tocospiro B (1.28\%), Cyclopentane, (4-octyldodecyl)(1.16\%), 4,22-Cholestadien-3-one (1.08\%), 6-Hydroxy-4,4,7atrimethyl-5,6,7,7a-tetrahydrobenzofuran-2(4H)-one $(1.05 \%)$, Bicyclo[4.1.0]heptan-3-one, 4,7,7-trimethyl-, [1R-(1.alpha., 4.beta.,6.alpha.)]- (1.02\%), 2,3a-Dimethylhexahydrobenzofuran7a-ol (1.02\%), 2-Methylhexacosane (1.02\%), Megastigmatrienone $(0.96 \%), \mathrm{N}, \mathrm{N}-\mathrm{Diethylhexylamine} \mathrm{(0.93 \% ),} \mathrm{Ergost-5-en-3-}$ ol, (3.beta.)- (0.93\%), Cholesta-4,6-dien-3-one (0.93\%), and D-Allose (0.84\%).

\section{Discussion}

The present study was carried out to investigate the effects of MECN on the central nervous system (Fig. 4), which is the first extensive study reporting the psychoactive potential of a member of the genus Crataeva. In hole cross and open field tests, the oral administration of MECN significantly suppressed spontaneous locomotor behavior of the animals indicating that MECN possesses at least some sedative properties. These observations were supported by a previously reported work, where the locomotor activity of 


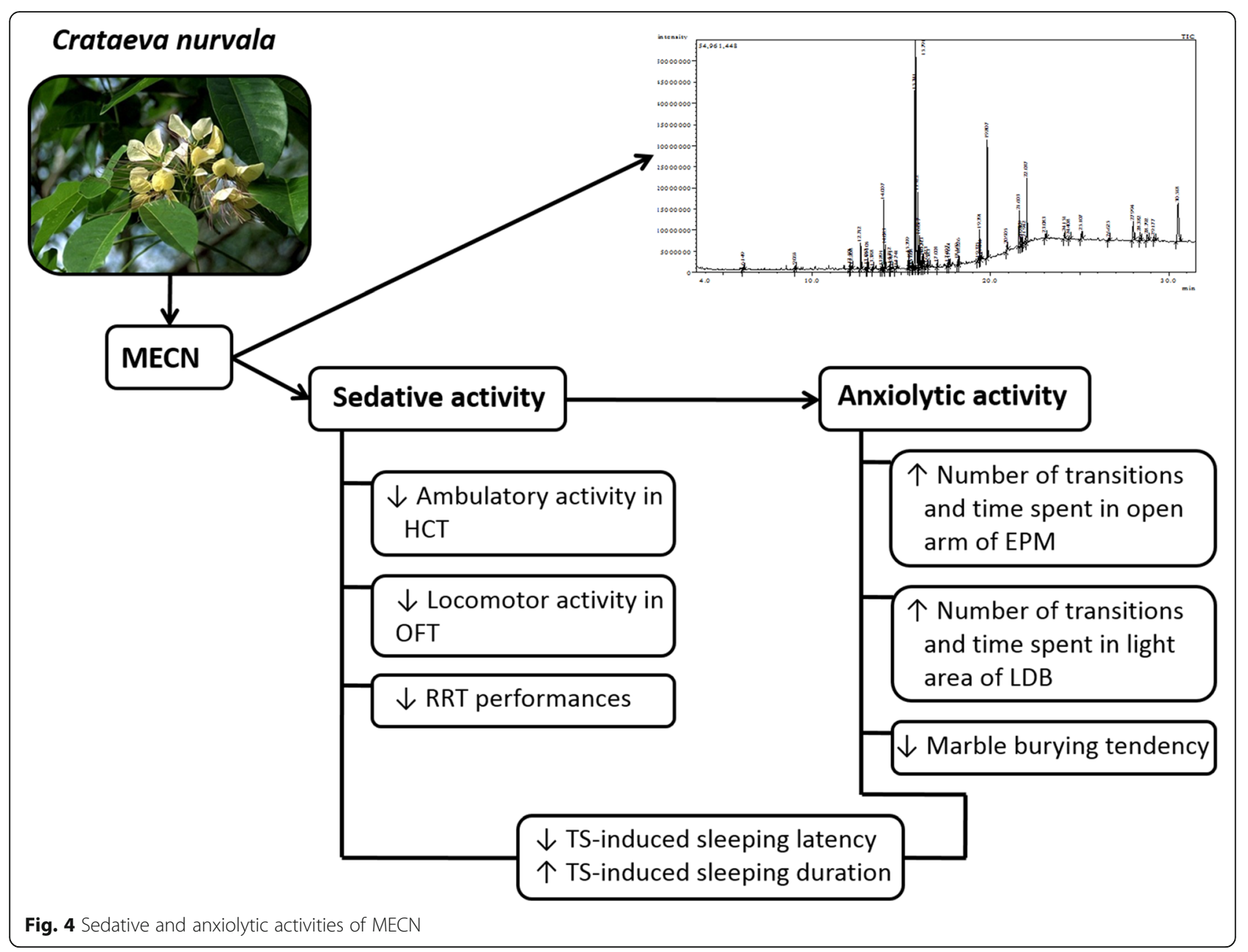

the animals was suppressed by MECN at $400 \mathrm{mg} / \mathrm{kg}$ dose [10]. Moreover, our earlier study revealed that MECN involves opioid system to show its antinociceptive effect in mice which was confirmed by using a non-specific opioid receptors antagonist, naloxone [8]. It has been reported that the opioid system inhibits GABAergic interneurons and directly affect the dopaminergic system to control locomotor behaviors [21]. Therefore, in agreement with these reports, it is conceivable that MECN may also involve opioid pathway to exhibit its sedative activity.

Motor coordination is a complex behavioral domain that reflects muscle strength, balance, and patterned gait [22]. It has been reported that barbiturates, benzodiazepines, and similar compounds can cause muscle weakness [23], sedation, and decrease ambulatory activity resulting in an impaired performance in rota-rod [24]. In our study, the administration of MECN and standard drug diazepam parallelly impaired motor co-ordination in rota-rod test, indicating that MECN has the capability to produce sedation that affects general activity and motor coordination of the mice.
To investigate the anxiolytic effect of MECN, we used EPM, a widely used animal model to scrutinize anxiolytic drugs. This experimental model acts based on the innate aversion of mice/rats to open place. In this test, the number of entries and total time spent in the open arms have generally been used as the indication of anxiolytic effect [25]. Like EPM, LDB is also a classical model of screening anxiolytic or anxiogenic drugs. LDB works based on the inherent unwillingness of rodents to enter into the brightly illuminated areas and on their spontaneous exploratory behaviors in response to mild stressors like light and novel environment. It has been reported that not the number of transitions but the time spent in the light area is the most consistent and useful parameter in investigation of anxiolytic action [26]. We found that MECN treatments influenced the animals to come in open and lighted areas of EPM and LDB, disclosing the anxiolytic potential of MECN. Moreover, the glass marbles in marble burying test provide an effective unconditioned stimulus which incites burying. This 
aversive stimulus has been reported sensitive to diazepam or chlordiazepoxide and suggested that the decrease in burying behavior will indicate the anxiolytic action of a drug candidate [19, 27]. Therefore, our findings in MBT suggest the prominent anxiolytic action of MECN which is consistent with the results obtained from EPM and LDB tests.

To confirm the possible involvement of GABAergic system in MECN-mediated sedative and anxiolytic activity, we co-administered thiopental sodium (TS) with MECN or diazepam. It is well established that the sedative and anxiolytic effect of benzodiazepines are due to their binding to $\mathrm{GABA}_{\mathrm{A}}$ receptor at a site distinct from the GABA binding site [28]. However, when barbiturates like TS binds with the barbituric acid binding sites of $\mathrm{GABA}_{\mathrm{A}}$ receptor complex, it potentiates GABA-mediated hyperpolarization of postsynaptic neurons [29]. Therefore, it has been suggested that the agents including natural products and chemical compounds which potentiate thiopental-induced sleeping, will potentially affect GABAergic neurotransmission [30, 31]. In corroboration with our results it is therefore conceivable that GABAergic system might have the contribution at least in a part in MECN-induced modulation of the sleeping behavior of animals produced by TS.

The qualitative phytochemical analysis identified the presence of alkaloids, glycosides, carbohydrates, flavonoids, and tannins in MECN. Although GC is mainly effective for identification of volatile compounds, we further analyzed MECN using GC/MS-MS due to the instrument availability and accessibility. Among others, D-Allose is the most active compound in MECN, reported to inhibit mitochondrial reactive oxygen species in Neuro2A cells [32] as well as protect the brain from transient ischemic neural death [33]. During cerebral ischemia, this compound also inhibited the production of inflammatory cytokines and translocation of NF- $\mathrm{KB}$ components to protect blood-brain barrier [34, 35]. Phytol was found to produce significant anxiolytic activity in mice which is mediated through its interaction with GABAergic system [36]. Moreover, it has also been reported that $\alpha$-Tocopherol (vitamin E) and other alkaloids, flavonoids, tannins, and terpenoids containing plant extracts possess strong sedative and anxiolytic and anticonvulsant effects on Swiss albino mice $[37,38]$. Although the direct involvements of individual components are yet to be revealed, accumulated evidence raise the possibility of these reported neuro-active components to participate at least in a part in the mechanism of sedative and anxiolytic actions of MECN.

\section{Conclusion}

Taken together, we conclude that MECN possesses strong sedative-and anxiolytic-like properties which may be mediated through the interactions with GABAergic system that affect the general activity, motor coordination and muscle strength of the animals. We also hypothesize that the observed effects are due to the presence of several psychoactive phytochemicals including phytol, D-allose, and $\alpha$-tocopherol in MECN. Therefore, further in-depth studies are required to isolate the bioactive phytochemical(s) and understand the precise molecular mechanisms underlying the observed pharmacological activities. In addition, we also believe that this work will act as an eye-opener regarding the central nervous system effect of the genus Crataeva and will serve as a basis for future research of MECN.

\section{Abbreviations \\ CNS: Central nervous system; EPM: Elevated plus maze; GC/MS-MS: Gas chromatography-mass spectroscopy-mass spectroscopy; HCT: Hole cross test; icddr,b: International Center for Diarrheal Disease and Research, Bangladesh; LDB: Light-dark box; MBT: Marble burying test; MECN: Methanol extract of $C$. nurvala leaves; OFT: Open field test; RRT: Rota-rod test; TS: Thiopental sodium \\ Acknowledgements \\ The authors are thankful to the Department of Pharmacy, Stamford University Bangladesh, for providing the basic facilities in the \\ Pharmacology Laboratory. \\ Funding \\ This research received no grant from any funding agency in the public, commercial, or not-for-profit sectors.}

\section{Availability of data and materials}

All data generated or analysed during this study are included in this published article. However, further details are available from the corresponding author on reasonable request.

\section{Authors' contributions \\ MM conceived and designed the experiments. All authors were involved in conducting the experiments. MM and MA analyzed the data. MM wrote the manuscript and MAM, MFHK, ABA, and MA read and approved the final version of the manuscript.}

\section{Ethics approval}

All experimental animals were treated following the Health guide for the care and use of Laboratory animals (1978) formulated by the National Institute of Health. All protocols conducted in this study comply with the ARRIVE guidelines and were approved by the Institutional Animal Ethics Committee of Stamford University Bangladesh (SUB/IAEC/14.09). Moreover, pentobarbital was used to euthanize the animals following AVMA guidelines for the Euthanasia of Animals (2013).

Consent for publication

Not applicable.

\section{Competing interests}

The authors wish to confirm that there are no known competing interests associated with this publication and there has been no significant financial support for this work that could have influenced its outcome.

\section{Publisher's Note}

Springer Nature remains neutral with regard to jurisdictional claims in published maps and institutional affiliations.

\section{Author details}

1Department of Pharmacy, Stamford University Bangladesh, 51 Siddeswari road, Dhaka 1217, Bangladesh. ²Designated Reference Institute for Chemical Measurement (DRiCM), Bangladesh Council of Scientific \& Industrial Research, Dhaka 1205, Bangladesh. ${ }^{3}$ Mater Research Institute - UQ at Translational Research Institute, Faculty of Medicine, The University of Queensland, Brisbane QLD 4102, Australia. 
Received: 6 April 2018 Accepted: 26 September 2018 Published online: 19 October 2018

\section{References}

1. Reynolds DS. The value of genetic and pharmacological approaches to understanding the complexities of GABA(a) receptor subtype functions: the anxiolytic effects of benzodiazepines. Pharmacol Biochem Behav. 2008;90: 37-42. https://doi.org/10.1016/j.pbb.2008.03.015.

2. Rickels K, Schweizer $\mathrm{E}$. The clinical presentation of generalized anxiety in primary-care settings: practical concepts of classification and management. J Clin Psychiatry. 1997:58(Suppl 11):4-10.

3. Carlini EA. Plants and the central nervous system. Pharmacol Biochem Behav. 2003:75:501-12

4. Zhang ZJ. Therapeutic effects of herbal extracts and constituents in anima models of psychiatric disorders. Life Sci. 2004;75:1659-99. https://doi.org/10. 1016/j.lfs.2004.04.014

5. Kirtikar KR, Basu BD. Indian medicinal plants. 2nd ed. India: International Book Publisher, Dehradun; 2005.

6. Bhattacharjee A, Shashidhara SC. Aswathanarayana. Phytochemical and ethno-pharmacological profile of Crataeva nurvala Buch-hum (Varuna): a review. Asian Pacific Journal of Tropical Biomedicine. 2012;2:S1162-8. https://doi.org/10.1016/S2221-1691(12)60379-7.

7. Ghani A. Medicinal Plant of Bangladesh with chemical constituents and uses. 2nd ed. Dhaka, Bangladesh: Asiatic Society of Bangladesh; 1998.

8. Moniruzzaman M, Imam MZ. Evaluation of antinociceptive effect of methanolic extract of leaves of Crataeva nurvala Buch.-ham. BMC Complement Altern Med. 2014;14:354. https://doi.org/10.1186/1472-6882-14-354.

9. Oliver-Bever B. Medicinal plants in tropical West Africa. II. Plants acting on the nervous system. J Ethnopharmacol. 1983;7:1-93.

10. Ali MS, Dey A, Abu Sayeed M, Rahman AA, Kuddus MR, Rashid MA. In vivo sedative and cytotoxic activities of methanol extract of leaves of Crataeva nurvala Buch-ham. Pak J Biol Sci. 2014;17:439-42

11. Walker Cl, Trevisan G, Rossato MF, Franciscato C, Pereira ME, Ferreira J, Manfron MP. Antinociceptive activity of Mirabilis Jalapa in mice. J Ethnopharmacol. 2008;120:169-75. https://doi.org/10.1016/j.jep.2008.08.002.

12. Takagi K, Watanabe M, Saito H. Studies of the spontaneous movement of animals by the hole cross test; effect of 2-dimethyl-aminoethanol and its acyl esters on the central nervous system. Jpn J Pharmacol. 1971;21:797-810.

13. Gupta BD, Dandiya PC, Gupta ML. A psycho-pharmacological analysis of behaviour in rats. Jpn J Pharmacol. 1971;21:293-8.

14. Dunham NW, Miya TS. A note on a simple apparatus for detecting neurological deficit in rats and mice. J Am Pharm Assoc. 1957:46:208-9. https://doi.org/10.1002/jps.3030460322.

15. Fujimori $\mathrm{H}$, Cobb DP. Central nervous system depressant activity of MA1337, 3-(3-(4-m-chlorophenyl-1-piperazyl)propyl)-2,4(1h,3h)quinazolinedione hydrochloride. J Pharmacol Exp Ther. 1965;148:151-7.

16. Pellow S, Chopin P, File SE, Briley M. Validation of open:closed arm entries in an elevated plus-maze as a measure of anxiety in the rat. J Neurosci Methods. 1985;14:149-67.

17. Bourin M, Hascoët M. The mouse light/dark box test. Eur J Pharmacol. 2003; 463:55-65. https://doi.org/10.1016/S0014-2999(03)01274-3.

18. Hascoët M, Bourin M. A new approach to the light/dark test procedure in mice. Pharmacol Biochem Behav. 1998:60:645-53.

19. Treit $D$, Pinel JP, Fibiger HC. Conditioned defensive burying: a new paradigm for the study of anxiolytic agents. Pharmacol Biochem Behav. 1981;15:619-26.

20. Ghani A. Medicinal plants of Bangladesh with chemical constituents and uses. Dhaka, Bangladesh: Asiatic Society of Bangladesh; 2003.

21. Johnson SW, North RA. Opioids excite dopamine neurons by hyperpolarization of local interneurons. J Neurosci. 1992:12:483-8.

22. Ginski MJ, Witkin JM. Sensitive and rapid behavioral differentiation of Nmethyl-D-aspartate receptor antagonists. Psychopharmacology. 1994;114: 573-82

23. López-Rubalcava C, Hen R, Cruz SL. Anxiolytic-like actions of toluene in the burying behavior and plus-maze tests: differences in sensitivity between 5 HT(1B) knockout and wild-type mice. Behav Brain Res. 2000;115:85-94

24. Estrada-Reyes R, López-Rubalcava C, Rocha L, Heinze G, González Esquinca AR, Martinez-Vázquez M. Anxiolytic-like and sedative actions of Rollinia mucosa: possible involvement of the GABA/benzodiazepine receptor complex. Pharm Biol. 2010;48:70-5. https://doi.org/10.3109/13880200903046153.

25. Kulkarni SK, Reddy DS. Animal behavioral models for testing antianxiety agents. Methods Find Exp Clin Pharmacol. 1996;18:219-30.
26. Young R, Johnson DN. A fully automated light/dark apparatus useful for comparing anxiolytic agents. Pharmacol Biochem Behav. 1991;40:739-43.

27. Poling A, Cleary J, Monaghan M. Burying by rats in response to aversive and nonaversive stimuli. J Exp Anal Behav. 1981:35:31-44.

28. Whiting PJ. GABA-A receptor subtypes in the brain: a paradigm for CNS drug discovery? Drug Discov Today. 2003:8:445-50.

29. Fernández S, Wasowski C, Paladini AC, Marder M. Sedative and sleepenhancing properties of linarin, a flavonoid-isolated from Valeriana officinalis. Pharmacol Biochem Behav. 2004;77:399-404.

30. de la Pena JB, Lee HL, Yoon SY, Kim GH, Lee YS, Cheong JH. The involvement of magnoflorine in the sedative and anxiolytic effects of Sinomeni caulis et Rhizoma in mice. J Nat Med. 2013;67:814-21. https:/doi.org/10.1007/s11418-013-0754-3.

31. Hossain MF, Talukder B, Rana MN, Tasnim R, Nipun TS, Uddin SM, Hossen SM. In vivo sedative activity of methanolic extract of Stericulia villosa Roxb. Leaves. BMC Complement Altern Med. 2016:16:398. https://doi.org/10.1186/ s12906-016-1374-8.

32. Ishihara Y, Katayama K, Sakabe M, Kitamura M, Aizawa M, Takara M, Itoh K Antioxidant properties of rare sugar D-allose: effects on mitochondrial reactive oxygen species production in Neuro2A cells. J Biosci Bioeng. 2011; 112:638-42. https://doi.org/10.1016/j.jbiosc.2011.08.005.

33. Liu Y, Nakamura T, Toyoshima T, Shinomiya A, Tamiya T, Tokuda M, Keep RF, Itano T. The effects of D-allose on transient ischemic neuronal death and analysis of its mechanism. Brain Res Bull. 2014;109:127-31. https://doi.org/10.1016/j.brainresbull.2014.10.005.

34. Huang T, Gao D, Hei Y, Zhang X, Chen X, Fei Z. D-allose protects the blood brain barrier through PPARgamma-mediated anti-inflammatory pathway in the mice model of ischemia reperfusion injury. Brain Res. 2016;1642:478-86. https://doi.org/10.1016/j.brainres.2016.04.038.

35. Shinohara N, Nakamura T, Abe Y, Hifumi T, Kawakita K, Shinomiya A, Tamiya T, Tokuda M, Keep RF, Yamamoto T, Kuroda Y. D-Allose attenuates overexpression of inflammatory cytokines after cerebral ischemia/ reperfusion injury in gerbil. J Stroke Cerebrovasc Dis. 2016;25:2184-8. https://doi.org/10.1016/j.jstrokecerebrovasdis.2016.01.030.

36. Costa JP, de Oliveira GA, de Almeida AA, Islam MT, de Sousa DP, de Freitas RM. Anxiolytic-like effects of phytol: possible involvement of GABAergic transmission. Brain Res. 2014;1547:34-42. https://doi.org/10. 1016/j.brainres.2013.12.003.

37. de Almeida ER, Rafael KR, Couto GB, Ishigami AB. Anxiolytic and anticonvulsant effects on mice of flavonoids, linalool, and alpha-tocopherol presents in the extract of leaves of Cissus sicyoides L. (Vitaceae). J Biomed Biotechnol. 2009;2009:274740. https://doi.org/10.1155/2009/274740.

38. Häberlein H, Tschiersch KP, Schäfer HL. Flavonoids from Leptospermum scoparium with affinity to the benzodiazepine receptor characterized by structure activity relationships and in vivo studies of a plant extract. Pharmazie. 1994:49:912-22.

39. Thavasi V, Leong LP, Bettens RP. Investigation of the influence of hydroxy groups on the radical scavenging ability of polyphenols. J Phys Chem A. 2006;110:4918-23. https://doi.org/10.1021/jp057315r.

40. Wilkemeyer MF, Menkari CE, Charness ME. Novel antagonists of alcohol inhibition of I1-mediated cell adhesion: multiple mechanisms of action. Mol Pharmacol. 2002:62:1053-60

41. Hossain MA, Izuishi $K$, Maeta H. Protective effects of D-allose against ischemia reperfusion injury of the rat liver. J Hepato-Biliary-Pancreat Surg. 2003;10:218-25. https://doi.org/10.1007/s00534-002-0785-8.

42. Hossain MA, Wakabayashi H, Goda F, Kobayashi S, Maeba T, Maeta H. Effect of the immunosuppressants FK506 and D-allose on allogenic orthotopic liver transplantation in rats. Transplant Proc. 2000;32:2021-3.

43. Murata A, Sekiya K, Watanabe Y, Yamaguchi F, Hatano N, Izumori K, Tokuda $M$. A novel inhibitory effect of D-allose on production of reactive oxygen species from neutrophils. J Biosci Bioeng. 2003;96:89-91.

44. Sui L, Dong Y, Watanabe $Y$, Yamaguchi F, Hatano N, Izumori K, Tokuda M. Growth inhibitory effect of D-allose on human ovarian carcinoma cells in vitro. Anticancer Res. 2005;25:2639-44.

45. Gong X, Zhou Q, Wang F, Wu W, Chen X. Efficacy and safety of ultrasoundguided percutaneous Polidocanol Sclerotherapy in benign cystic thyroid nodules: preliminary results. Int J Endocrinol. 2017;2017:8043429. https://doi. org/10.1155/2017/8043429

46. Star P, Connor DE, Parsi K. Novel developments in foam sclerotherapy: focus on Varithena(R) (polidocanol endovenous microfoam) in the management of varicose veins. Phlebology. 2017:268355516687864. https://doi.org/10. $1177 / 0268355516687864$ 
47. Chen SS, Zhang Y, Lu QL, Lin Z, Zhao Y. Preventive effects of cedrol against alopecia in cyclophosphamide-treated mice. Environ Toxicol Pharmacol. 2016;46:270-6. https://doi.org/10.1016/j.etap.2016.07.020.

48. Zhang SY, Li XB, Hou SG, Sun Y, Shi YR, Lin SS. Cedrol induces autophagy and apoptotic cell death in A549 non-small cell lung carcinoma cells through the P13K/Akt signaling pathway, the loss of mitochondrial transmembrane potential and the generation of ROS. Int J Mol Med. 2016; 38:291-9. https://doi.org/10.3892/ijmm.2016.2585.

49. Zhang Y, Han L, Chen SS, Guan J, Qu FZ, Zhao YQ. Hair growth promoting activity of cedrol isolated from the leaves of Platycladus orientalis. Biomed Pharmacother. 2016;83:641-7. https://doi.org/10.1016/j.biopha.2016.07.022.

50. Fang Z, Jeong SY, Jung HA, Choi JS, Min BS, Woo MH. Anticholinesterase and antioxidant constituents from Gloiopeltis furcata. Chem Pharm Bull (Tokyo). 2010;58:1236-9.

51. Guo J, Yuan Y, Lu D, Du B, Xiong L, Shi J, Yang L, Liu W, Yuan X, Zhang G, Wang F. Two natural products, trans-phytol and (22E)-ergosta-6,9,22-triene3beta,5alpha,8alpha-triol, inhibit the biosynthesis of estrogen in human ovarian granulosa cells by aromatase (CYP19). Toxicol Appl Pharmacol. 2014; 279:23-32. https://doi.org/10.1016/.ttaap.2014.05.008.

52. Saikia D, Parihar S, Chanda D, Ojha S, Kumar JK, Chanotiya CS, Shanker K, Negi AS. Antitubercular potential of some semisynthetic analogues of phytol. Bioorg Med Chem Lett. 2010;20:508-12. https://doi.org/10.1016/j.bmcl.2009.11.107.

53. Teal PE, Tumlinson JH, Heath RR. Chemical and behavioral analyses of volatile sex pheromone components released by callingHeliothis virescens ( $F$.) females (Lepidoptera: Noctuidae). J Chem Ecol. 1986;12:107-26. https:/doi.org/10.1007/ bf01045595.

54. Himmelfarb J, Phinney S, Ikizler TA, Kane J, McMonagle E, Miller G. Gammatocopherol and docosahexaenoic acid decrease inflammation in dialysis patients. J Ren Nutr. 2007;17:296-304. https://doi.org/10.1053/j.jn.2007.05.011.

55. Muid S, Froemming GR, Rahman T, Ali AM, Nawawi HM. Delta- and gammatocotrienol isomers are potent in inhibiting inflammation and endothelial activation in stimulated human endothelial cells. Food Nutr Res. 2016;60: 31526. https://doi.org/10.3402/fnr.v60.31526.

56. Traber MG, Atkinson J. Vitamin E, antioxidant and nothing more. Free Radic Biol Med. 2007;43:4-15. https://doi.org/10.1016/j.freeradbiomed.2007.03.024.

57. Adnan SN, Ibrahim N, Yaacob WA. Transcriptome analysis of methicillinresistant Staphylococcus aureus in response to stigmasterol and lupeol. J Glob Antimicrob Resist. 2017;8:48-54. https://doi.org/10.1016/j.jgar.2016.10.006

58. Aminu R, Umar IA, Rahman MA, Ibrahim MA. Stigmasterol retards the proliferation and pathological features of Trypanosoma congolense infection in rats and inhibits trypanosomal sialidase in vitro and in silico. Biomed Pharmacother. 2017;89:482-9. https://doi.org/10.1016/j.biopha.2017.02.068.

59. Antwi AO, Obiri DD, Osafo N. Stigmasterol modulates allergic airway inflammation in Guinea pig model of ovalbumin-induced asthma. Mediat Inflamm. 2017;2017:2953930. https://doi.org/10.1155/2017/2953930.

60. Gade S, Rajamanikyam M, Vadlapudi V, Nukala KM, Aluvala R, Giddigari C, Karanam NJ, Barua NC, Pandey R, Upadhyayula VS, Sripadi P, Amanchy R, Upadhyayula SM. Acetylcholinesterase inhibitory activity of stigmasterol \& hexacosanol is responsible for larvicidal and repellent properties of Chromolaena odorata. Biochim Biophys Acta. 2017;1861: 541-50. https://doi.org/10.1016/j.bbagen.2016.11.044.

61. Ahn EK, Oh JS. Lupenone isolated from Adenophora triphylla var. japonica extract inhibits adipogenic differentiation through the downregulation of PPARgamma in 3T3-L1 cells. Phytother Res. 2013;27: 761-6. https://doi.org/10.1002/ptr.4779.

62. Villareal MO, Han J, Matsuyama K, Sekii Y, Smaoui A, Shigemori H, Isoda H. Lupenone from Erica multiflora leaf extract stimulates melanogenesis in B16 murine melanoma cells through the inhibition of ERK1/2 activation. Planta Med. 2013;79:236-43. https://doi.org/10.1055/s-0032-1328189.

63. Xu F, Wu H, Wang X, Yang Y, Wang Y, Qian H, Zhang Y. RP-HPLC characterization of lupenone and beta-sitosterol in rhizoma musae and evaluation of the antidiabetic activity of lupenone in diabetic Sprague-Dawley rats. Molecules. 2014;19: 14114-27. https:/doi.org/10.3390/molecules190914114.

64. Yoon YP, Lee HJ, Lee DU, Lee SK, Hong JH, Lee CJ. Effects of Lupenone, Lupeol, and Taraxerol derived from Adenophora triphylla on the gene expression and production of airway MUC5AC Mucin. Tuberc Respir Dis (Seoul). 2015;78:210-7. https://doi.org/10.4046/trd.2015.78.3.210.

\section{Ready to submit your research? Choose BMC and benefit from:}

- fast, convenient online submission

- thorough peer review by experienced researchers in your field

- rapid publication on acceptance

- support for research data, including large and complex data types

- gold Open Access which fosters wider collaboration and increased citations

- maximum visibility for your research: over $100 \mathrm{M}$ website views per year

At BMC, research is always in progress.

Learn more biomedcentral.com/submissions 